\title{
CEREBROCRANIAL DIFFERENTIATION OF THE ARCTIC CHARR [SALVELINUS ALPINUS (L.)] IN WATER BODIES OF THE HORNSUND REGION (SPITSBERGEN)
}

\section{ZRÓŻNICOW ANIE MÓZGOCZASZKI GOLCA [SAL VELINUS ALPINUS (L.)] ZE ZBIORNIKÓW REJONU HORNSUNDU (SPITSBERGEN)}

\author{
Faculty of Marine Fisheries and Food Technology \\ Academy of Agriculture \\ Szczecin, Poland
}

Measurements of the cerebrocranium of the Arctic charr (Salvelinus alpinus) from River Revelva and Lake Svartvatnet on Spitsbergen were made. The fishes from the two water bodies differed in the shape and size of their various cerebrocranial elements.

As a continuation of osteologic studies on the Arctic charr [Salvelinus alpinus (L.)] from the water bodies of Hornsund (Spitsbergen) (Sobociński and Radziun, this volume), measurements were made on the cerebrocranium of 39 individuals (11 males, 17 females, 11 individuals of non-determined sex) caught in Lake Svartvatnet (26 individuals), River Revelva ( 3 individuals), and in the Revelva mouth (10 individuals). The following cranial parameters were measured (to $0.01 \mathrm{~cm}$ ): cranial length (1.cr.), width at the os ethmoidale laterale level (s.eth.), width at the os sphenoticum level (s.sph.), width at the os pteroticum level (s.pte.), height at the os ethmoidale laterale level (h.eth.), height at the os sphenoticum level (h.sph.), and height at the ossa occipitale level (h.occ.) (Fig. 1) (Šapošnikova, 1968).

Similarly to the differentiation of skull bones described elsewhere (Sobocinski and Radziun, this volume), the shape of the cerebrocranium showed considerable differences. 

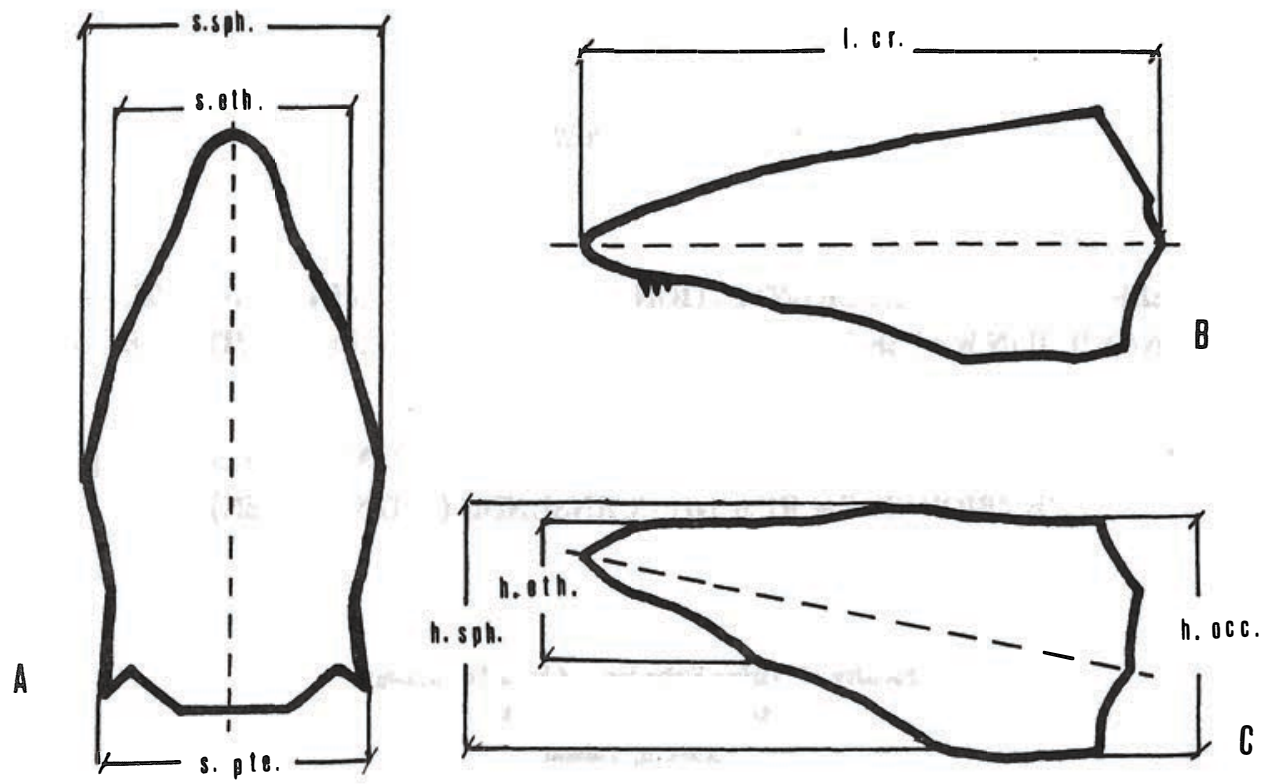

Fig. 1. Schematic of cerebrocranial measurements on the skull of Arctic charr [Salvelinus alpinus (L.)]; abbreviations explained in the text

A total of 9 parameters, created by calculating ratios of skull heights, lengths and widths at various levels, were analyzed. The parameters are as follows:

1. (h.eth./1.cr.)*100 (\%)

3. (h.occ./l.cr.)*100 (\%)

5. (s.sph./1.cr.)*100 (\%)

7. (h.eth./s.eth.)*100 (\%)

9. (h.occ./s.pte.)*100 (\%)
2. (h.sph./1.cr.)*100(\%)

4. (S.eth./l.cr.)*100(\%)

6. (s.pte./l.cr.)*100 (\%)

8. (h.sph./s.sph.) $* 100(\%)$

A preliminary test for between-sexes differences in each parameter was made; those parameters showing statistically significant between-sexes differences were excluded from the analysis (parameters 4 and 7, Table 1). The remaining parameters, i.e. those not affected meaningfully by the sexual dimorphism, were subject to 1-way analysis of variance (Table 2). Statistically significant differences between the River Revelva and Lake Svartvatnet individuals were found in most parameters $(2,3,6,8)$ (Fig. 2). Thus the preliminary suggestion that the fishes caught in two water bodies differed in shape and size of their cerebrocranium was confirmed. The Revelva fish cerebrocranium is higher in its central and posterior part and wider in its posterior part (in relation to the skull length) than that of the Svartvatnet fish. It seems then that the two groups of individuals belong to two different, isolated stocks. 
parsmetr 2

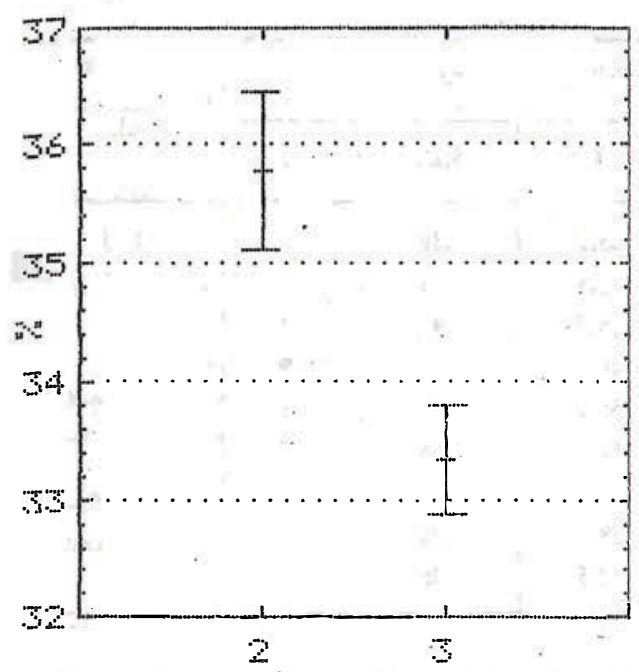

Fievelwa parametr $\leq$

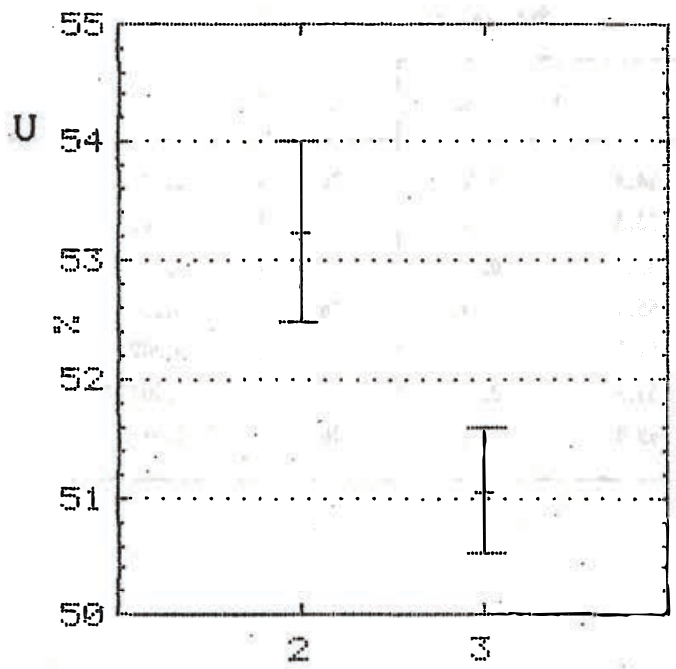

Fienel wa

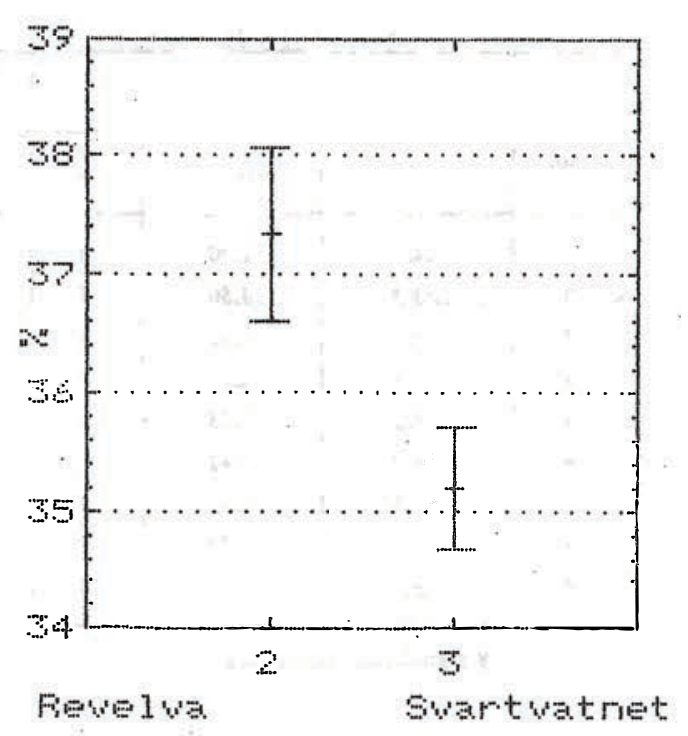

Parametr 3

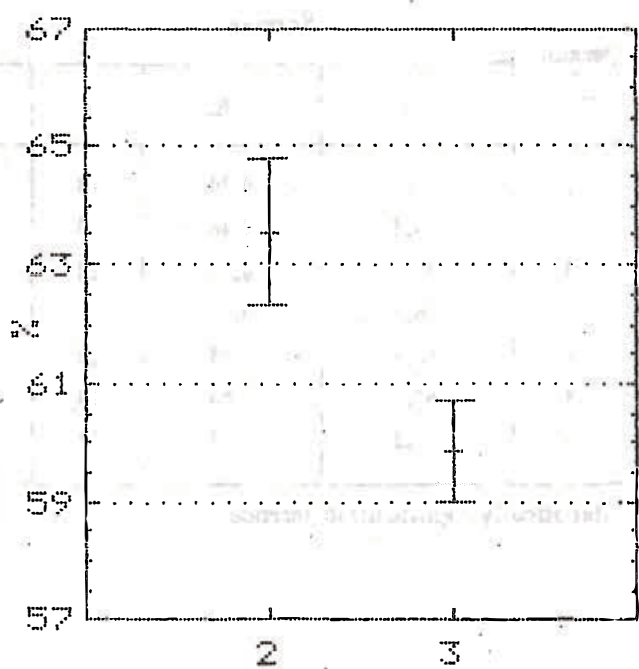

Swartwatriet

Fig. 2. Confidence intervals in 1-way analysis of variance for certain cerebrocranial parameters of Arctic charr [Salvelinus alpinus ( $\left.\mathrm{L}_{0}\right)$ ] from Hornsund water bodies 
Table 1

Test of differences for cerebrocranial parameters of males and females of Arctic charr

[Salvelinus alpinus $\left(\mathrm{L}_{\circ}\right)$ ] in Hornsund water bodies $(\alpha=0.05)$

\begin{tabular}{|c|c|c|c|c|c|c|c|}
\hline \multirow{2}{*}{$\begin{array}{c}\text { param. } \\
\text { no. }\end{array}$} & \multicolumn{3}{|c|}{ males } & \multicolumn{3}{|c|}{ females } & \multirow{2}{*}{ S.l. } \\
\hline & $\tilde{\bar{x}}$ & S.D. & $\mathrm{n}$ & $\bar{x}$ & S.D. & $\mathrm{n}$ & \\
\hline 1 & 24.4 & 1.00 & 11 & 25.1 & 1.80 & 17 & 0.13 \\
\hline 2 & 33.3 & 0.86 & 11 & 33.6 & 2.16 & 17 & 0.37 \\
\hline 3 & 35.5 & 1.61 & 11 & 35.2 & 2.47 & 17 & 0.40 \\
\hline 4 & 41.8 & 2.19 & 11 & 40.2 & 2.31 & 17 & $0.047 *$ \\
\hline 5 & 55.1 & 1.23 & 11 & 56.1 & 1.87 & 17 & 0.067 \\
\hline 6 & 50.7 & 2.42 & 11 & 51.4 & 1.68 & 17 & 0.18 \\
\hline 7 & 58.5 & 4.32 & 11 & 62.6 & 6.22 & 17 & $0.037^{*}$ \\
\hline 8 & 60.5 & 1.30 & $1 i$ & 59.8 & 3.92 & 17 & 0.31 \\
\hline 9 & 69.9 & 2.69 & 11 & 68.5 & 4.35 & 17 & 0.17 \\
\hline
\end{tabular}

*statistically significant difference

Table 2

Oneway analysis of variance for cerebrocranial parameters of Arctic charr

[Salvelinus alpinus $\left(\mathrm{L}_{\circ}\right)$ ] in Hornsund water bodies $(\alpha=0.05)$

\begin{tabular}{c|c|c|c|c|c|c|c}
\hline \multirow{2}{*}{\begin{tabular}{c|c|c|c|c|} 
param. \\
no.
\end{tabular}} & \multicolumn{3}{|c|}{ Revelva } & \multicolumn{3}{c|}{ Svartvatnet } & \multirow{2}{*}{ s.1. } \\
\cline { 2 - 6 } & $\overline{\overline{\mathrm{x}}}$ & S.E. & $\mathrm{n}$ & $\overline{\mathrm{x}}$ & S.E. & $\mathrm{n}$ & \\
\hline 1 & 25.1 & 0.39 & 13 & 24.8 & 0.28 & 26 & 0.54 \\
2 & 35.8 & 0.46 & 13 & 33.3 & 0.33 & 26 & $0.0001^{*}$ \\
3 & 37.3 & 0.52 & 13 & 35.2 & 0.37 & 26 & $0.017^{*}$ \\
5 & 56.3 & 0.45 & 13 & 55.7 & 0.31 & 26 & 0.28 \\
6 & 53.2 & 0.53 & 13 & 51.1 & 0.38 & 26 & $0.002^{*}$ \\
8 & 63.6 & 0.86 & 13 & 59.9 & 0.61 & 26 & $0.0012^{*}$ \\
9 & 70.2 & 1.03 & 13 & 69.0 & 0.72 & 26 & 0.34 \\
\hline
\end{tabular}

*statistically significant difference 


\section{REFERENCE了}

Sobocinioki $A_{0}$, Ko Redriun, 1993: Preliminary osteological studies on the Arctic chanr, Salvelinus alpinus (L., 1758) from the Hornsund region (Spitsbergen). Acta Ichth. Pisc. 23, Suppl. 37-46.

Saposnikikova G.H.t. 1968: Sravnitelno-morfologiceskij analiz sigov Sovetskogo Sojuza. Tr. Żool. In-ta AN SSSR, 46.

Translated: Dr. T. Radziejewska

Author's address:

Received: 1991.05 .24

mgr inż. Andrzej Sobocinóski

Zakład Anatomii i Embriologii Ryb

Akademia Rolnicza

ul. K. Krölewicza 4

71-550 Szczecin

Polska (Poland) 